\title{
Endoscopic radiofrequency ablation of a cholangiocarcinoma with targeted intraductal cholangioscopic access
}

Radiofrequency ablation (RFA) is a technique that has been used during endoscopic retrograde cholangiopancreatography (ERCP) for palliation of locally advanced biliary malignancies [1]. Direct cholangioscopy can be useful for confirming a successful response to therapy [2]. We present a case evaluating the feasibility of intraductal RFA using cholangioscopy (SpyGlass DS System) in a malignant biliary stricture [3].

An 83-year-old woman presented with a 1-month history of jaundice and weight loss. Her serum bilirubin level was $10.50 \mathrm{mg} / \mathrm{dL}$. An abdominal computed tomography (CT) scan revealed an intrahepatic biliary dilatation and dilated $(16 \mathrm{~mm})$ common bile duct (CBD). ERCP showed a 2.5-cm tight distal CBD stricture with upstream biliary dilatation, and a fully covered metal stent was placed. Brush cytology confirmed the suspicion of cholangiocarcinoma.

Primary endobiliary RFA was offered to the patient and informed consent was obtained. The duodenoscope passed the ampulla and a cholangiogram showed the dilated biliary tree above the distal biliary stricture. A digital cholangioscope (SpyGlass) was inserted into the bile duct, and the stricture was visualized revealing a nodular lesion with irregular mucosa ( $\triangleright$ Video 1 ). Intraductal RFA was performed advancing into the stricture, using $10 \mathrm{~W}$ for a time period of 2 minutes under $75{ }^{\circ} \mathrm{C}$ of intraductal temperature. The cholangioscope was reinserted and showed successfully ablated tissue with localized necrosis ( $>$ Fig. 1). Finally, an uncovered metal stent was deployed (WallFlex; $10 \times 60 \mathrm{~mm}$ ) ( Video 1). The patient was discharged the following day without any complications.

Endobiliary RFA that is targeted using cholangioscopy adds to the endoscopic armamentarium for the treatment of unresectable malignant obstructive neo-

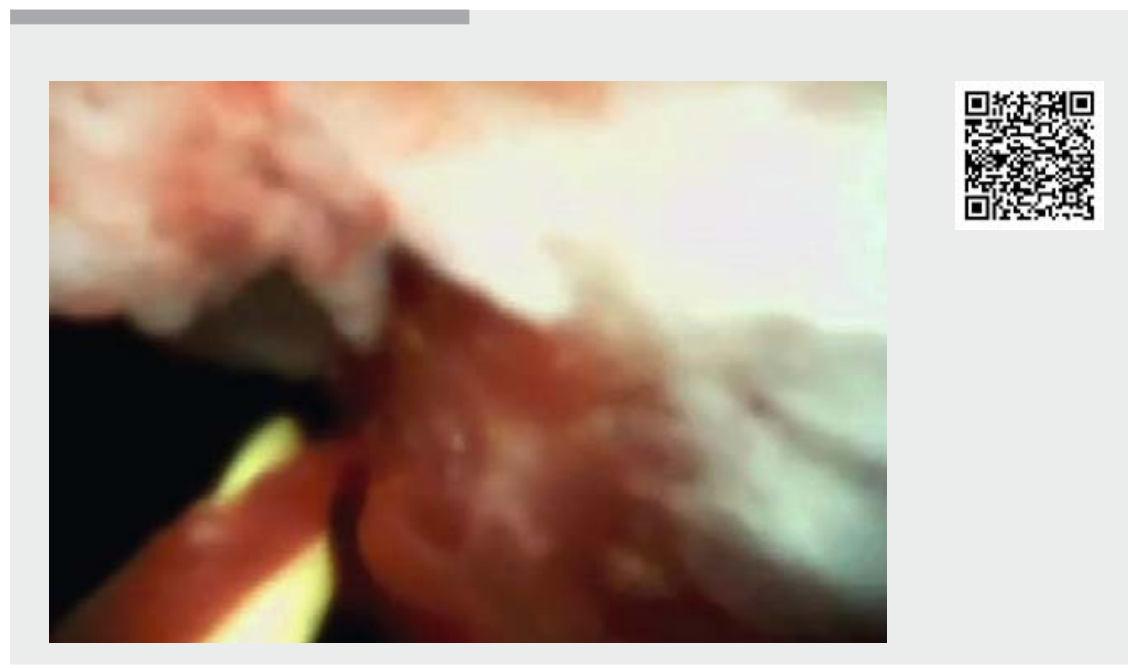

Video 1 Endobiliary radiofrequency ablation is used to treat an unresectable bile duct cancer.

plasms; moreover, it is possible to confirm the successful ablation of malignant strictures after RFA.

In conclusion, endobiliary RFA seems to be safe and effective as a treatment modality for unresectable bile duct cancer.

Endoscopy_UCTN_Code_TTT_1AR_2AF

\section{Competing interests}

The authors declare that they have no conflict of interest.

The authors

Lidia Marti Romero' ${ }^{1}$, Vanesa Martínez

Escapa ${ }^{1}$, Inmaculada Castelló Miralles², German Lacal Gutierrez ${ }^{3}$, Carmen Ivars

Párraga $^{4}$, Gloria Alemany Perez ${ }^{1}$, Jose Manuel Querol Ribelles ${ }^{5}$

1 Department of Digestive Diseases, Hospital Francesc de Borja, Valencia, Spain

2 Department of Digestive Diseases, Consorci Hospital General Universitari de Valencia, Valencia, Spain

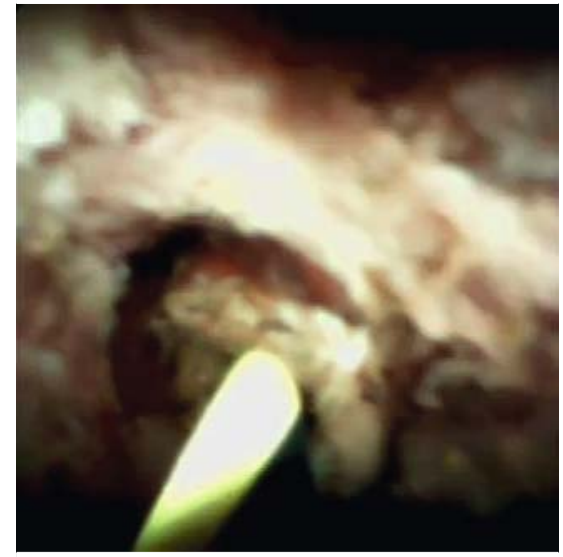

- Fig. 1 Images following reinsertion of the intraductal cholangioscope showing successfully ablated tissue with localized necrosis.

3 Department of Industrial Engineering,

4 Department of Anesthesia, Hospital Francesc de Borja, Valencia, Spain

5 Department of Internal Medicine, Hospital Francesc de Borja, Valencia, Spain University of Valencia, Valencia, Spain 
Corresponding author

\section{Vanesa Martínez Escapa, MD}

Hospital Francesc de Borja, Digestive

section, Avenida de la Medicina, Gandia,

Valencia 46702, Spain

Fax: +34-962-849500

Vanescapa@hotmail.com

\section{References}

[1] Brown N, Camilo ], McCarter M et al. Refractory jaundice from intraductal papillary mucinous neoplasm treated with cholangioscopy-guided radiofrequency ablation. ACG Case Rep J 2016; 3: 202-204

[2] Tyberg A, Zerbo S, Sharaiha R et al. Digital cholangioscopy: assessing the impact of radiofrequency ablation. Endoscopy 2015; 47 (Suppl. 01): E544

[3] Mavrogenis G, Deprez P, Wallon J et al. Bile duct adenoma causing recurrent cholangitis: diagnosis and management with targeted SpyClass access and radiofrequency ablation. Endoscopy 2012; 44 (Suppl. 02): E290-E291

\section{Bibliography}

Endoscopy 2021; 53: E58-E59

DOI 10.1055/a-1174-5399

ISSN 0013-726X

published online 19.6.2020

(c) 2020. Thieme. All rights reserved.

Georg Thieme Verlag KG, Rüdigerstraße 14, 70469 Stuttgart, Germany
ENDOSCOPY E-VIDEOS

https:/|eref.thieme.de/e-videos

口回 Endoscopy E-Videos is a free Fection, reporting 田: on interesting cases and new techniques in gastroenterological endoscopy. All papers include a high quality video and all contributions are freely accessible online.

This section has its own submission website at https://mc.manuscriptcentral.com/e-videos 